\title{
Louis-Philippe Hébert, Le livre des plages
}

\section{Lucie Picard}

\section{(2) OpenEdition}

\section{Journals}

\section{Édition électronique}

URL : http://journals.openedition.org/studifrancesi/8121

DOI : 10.4000/studifrancesi.8121

ISSN : 2427-5856

\section{Éditeur}

Rosenberg \& Sellier

\section{Édition imprimée}

Date de publication : 1 juillet 2009

Pagination : 458

ISSN : 0039-2944

\section{Référence électronique}

Lucie Picard, «Louis-Philippe Hébert, Le livre des plages », Studi Francesi [En ligne], 158 (LIII | II) | 2009, mis en ligne le 30 novembre 2015, consulté le 13 janvier 2021. URL : http://journals.openedition.org/ studifrancesi/8121; DOI : https://doi.org/10.4000/studifrancesi.8121

\section{Ce document a été généré automatiquement le 13 janvier 2021.}

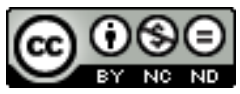

Studi Francesi è distribuita con Licenza Creative Commons Attribuzione - Non commerciale - Non opere derivate 4.0 Internazionale. 


\title{
Louis-Philippe Hébert, Le livre des plages
}

\author{
Lucie Picard
}

\section{RÉFÉRENCE}

LOUIS-PHILIPPE HÉBERT, Le livre des plages, Montréal, Les Herbes rouges, 2007 («Poésie»), pp. 292.

«J'essaie toujours de trouver les contraintes qui me libèreront». Ces paroles de l'écrivaine Nancy Huston, Louis-Philippe Hébert, poète et informaticien, pourrait aisément les reprendre à son compte car le volumineux recueil de poèmes qu'il nous livre constitue une illustration particulièrement convaincante de la fécondité d'une démarche d'écriture fortement encadrée. Ici, tout part d'un lieu: la plage, univers des vacances de l'enfance de l'auteur, les plages plutôt, puisque la famille Hébert fréquentera successivement divers lieux de villégiature (nord-américains ou européens). La plage, dans les 91 poèmes (en vers - surtout - ou en prose) du livre, c'est d'abord et avant tout une expérience sensorielle, rendue avec une étonnante fraîcheur du regard. Les énumérations abondent, mettant en place les éléments, naturels ou non, qui composent ce décor, évoquant avec vigueur et précision les sensations associées aux séjours au bord de la mer. Au cœur du projet qui fonde le recueil, il y a cela: une vaste entreprise de nomination. Dans le lieu ainsi campé, l'auteur met fréquemment en scène un imaginaire social satirique réjouissant mais inquiétant, sous forme de tableaux ou de saynètes.

2 Présence centrale dans le recueil, un sujet lyrique masculin dit ses rapports avec cet environnement matériel et humain, l'expérimentant tour à tour comme réservoir de sensations, puis comme tremplin pour une réflexion philosophique (rendue dans son incertitude ou avec un humour dévastateur), et comme espace qui accueille et modèle les affects. Or la sphère affective se caractérise principalement par une volonté, une revendication, de sa propre différence: refus de s'identifier à la foule des estivants, de 
se livrer à la mer qui déstructure tout «château de sable» (métaphore du cœur). Les images en ce sens abondent: crabes et homards, escargots et colimaçons, et jusqu'à la stricte division des deux sections des cartes postales... Seules ouvertures à l'autre: celle que ménage le désir (bisexuel), celle de l'amour (rarissime, notamment celui, béni, pour la petite sœur). Particulièrement lisible sans pourtant être lisse, l'écriture d'Hébert sait restituer dissonances et malaises, susciter l'intérêt, voire l'étonnement. Bien plus qu'un album de souvenirs, Le livre des plages relève avec bonheur un double défi: nous donner le monde, une partie de notre monde, nous le rendant tout à la fois familier et mystérieux; dire le caractère fondateur de la sensation, et le travail d'une subjectivité se construisant - par l'accueil ou le rejet, par l'élaboration - à partir de ses données inéluctables. 